\title{
Voting and social inclusion in Sweden ${ }^{1}$
}

\author{
Pieter Bevelander and Ravi Pendakur ${ }^{2}$
}

\begin{abstract}
Three decades ago, Sweden extended municipal and provincial voting privileges to noncitizen residents arguing that it would increase political influence, interest and selfesteem among foreign citizens. More recently, electoral participation on the part of immigrants is perceived as being substantially lower than for native-born citizens and questions have arisen regarding the degree to which this may be symptomatic of a larger integration issue. The aim of this paper is to explore the determinants of voting within the context of social inclusion by comparing immigrants, their descendants and native citizens in Sweden while controlling for a range of socio-economic, demographic characteristics, contextual factors and a set of "hard" and "soft" social inclusion related variables.

We use the Swedish 2006 electoral survey matched to registry data from Statistics Sweden to assess the correlates of voting by Swedish-born and immigrant residents. Using instrumental variable regressions to control the impact of citizenship acquisition, we find that immigrants are less likely to vote than native-born Sweden. Similar to other research, we find that age, education and income are important determinants of voting. However, we also find that acquisition of citizenship makes a real difference to the probability of voting. Immigrants who naturalise are in general far more likely to vote than those who do not.
\end{abstract}

Keywords: Political participation, Immigrants, Descendants, Electoral participation, Human capital, Citizenship, Social Inclusion

\footnotetext{
${ }^{1}$ We wish to thank Patrick Fafard, Krishna Pendakur, Jhoanna G. Miners and Richard Öhrvall for their comments and suggestions.

${ }^{2}$ Pieter Bevelander is a researcher at the Malmö Institute for Migration, Diversity and Welfare, Malmö University, Sweden. Email: Pieter.bevelander@mah.se

Ravi Pendakur is an assistant professor in Public and International Affairs at the University of Ottawa, Canada. Email: pendakur@uottawa.ca
} 


\section{Introduction}

Voting in free elections is often viewed as the most basic and important form of political participation. As such, the level of participation can be seen as an indicator of how well democracy is faring. On this yardstick, electoral participation in Sweden is high compared to other democratic countries. Over 80 percent of eligible voters exercised their franchise in the 2006 national, provincial and local elections. ${ }^{3}$

Immigration to Sweden over the last 50 years has been substantial. In 2006, 13 percent of the population, or about 1.2 million individuals residing in the country, were born abroad. There are an additional 300,000 people born in Sweden who are the children of immigrants (about 4 percent of the population). Sweden was one of the first countries to extend local and provincial voting rights to immigrants with resident status, arguing that it would increase social and political inclusion among foreign born residents (SOU 1975, 15). At the same time, Sweden liberalized citizenship acquisition policies. Three decades later, voting on the part of foreign born residents is substantially lower than for native-born and naturalized citizens (see Öhrvall 2006). To our minds, this could be evidence of a larger social inclusion issue. The aim of this paper is to explore the act of voting as a measure of social inclusion by comparing voting propensities of immigrants, their descendants and native citizens in Sweden after controlling for a range of contextual, socio-economic and demographic characteristics. In particular we focus on the impact of citizenship acquisition - does the symbolic act of attaining citizenship result in increased voting participation on the part of foreign-born residents and their descendents.

We find that overall, immigrants are less likely to vote than native-born Swedes even after controlling for contextual, demographic and socio-economic factors. However, the probability of voting increases dramatically for the descendants of immigrants who are born in Sweden. Similar to other research, we find that age, education and income are

\footnotetext{
${ }^{3}$ We note that all three elections take place on the same day. This means that voter turnout is about the same across municipal and provincial elections. The elections of 2006 are particularly interesting because they represent a reversal in the downward trend in electoral participation in Sweden.
} 
important determinants of voting. However, we also find that acquisition of citizenship makes a real difference to the probability of voting. Immigrants who naturalise are in general far more likely to vote than those who do not

\section{Research question:}

Our goal is to assess the degree to which differences in voting probabilities are a product of immigrant status and citizenship, controlling for a broad set of demographic, socioeconomic and contextual characteristics. We focus upon three primary categories of residents. Ethnic Swedes born in Sweden constitute the primary comparison group. We also examine eight country of birth groups with permanent residency. Finally we include two groups who are the descendents of immigrants, who do not necessarily have citizenship by right of birth. The primary questions we ask are:

- To what extent are there differences in voting participation across immigrant and Swedish-born categories?

If there are differences, to what extent are they explained by contextual, demographic and socio-economic factors, human capital attributes and immigration related factors?

Does the act of citizenship acquisition serve to increase voter participation?

Of particular interest is the fact that we examine these issues through a social inclusion lense because we view both citizenship and voting as symbolically important inclusionary processes.

We use the 2006 Swedish electoral survey which contains information on individual electoral participation in national, provincial and municipal elections. This information was matched to registry data from Statistics Sweden which contains socio-economic and demographic characteristics for every Swedish resident. From these two sources, we are able to create a database which matches voting to individual characteristics for more than 70,000 residents of which 13,000 do not have Swedish citizenship but are eligible to vote in municipal. We first provide a historical overview of immigration to Sweden followed by an examination of past research on political participation and inclusion. With this understanding in hand we then assess the degree to which voting differs across socio- 
demographic and immigrant groups with particular emphasis on citizenship acquisition and long term integration.

\section{Context}

\section{Immigration}

From World War II to the early 1970s, immigration to Sweden was mainly Nordic and European, characterized by labour force immigration. During this time, Sweden’s economy expanded rapidly due in part to reconstruction efforts in neighbouring countries. Labour shortages in Sweden were resolved in the 1950s through the import of skilled labour through immigration which served to complement the native labour force. This skilled labour was mainly recruited from northwestern Europe, with the majority coming from West Germany and the Nordic countries.

The 1960s saw a shift in the labour force toward unskilled or low-skilled (often imported) workers. In contrast to their counterparts a decade earlier, these workers were used more as a substitute for the native workforce rather than as a complement. While earlier immigrants allowed the economy to grow in size, the immigrants of the 1960s facilitated a widening of the economy. These new immigrants found low-skill industrial jobs vacated by Swedes during the expansion of the service sector. The fact that these newly vacated jobs could be filled by unskilled workers resulted from a massive industrial investment aimed at increasing international competitiveness and reducing costs (Lundh and Ohlsson 1999). In addition to immigrants from Nordic countries, immigrants from the Mediterranean such as Greece, Yugoslavia and Turkey also began to migrate to Sweden.

During the 1960s, there were no working visa restrictions. Migrant workers could simply show up in Sweden on a tourist visa. By the end of the 1960s, the situation began to change for immigrants. Fuelled by trade unions, the state changed the rules governing entrance into Sweden. The new rules, implemented in 1968, meant that future applicants for work and residence permits from non-Nordic countries had to apply before they entered the country. Simultaneously, the applicant needed to arrange for both a job and a 
place to live. This dramatically decreased labour immigration from non-Nordic countries.

Sweden's economic growth dropped substantially following the oil shock of the early 1970s. As with many western countries, the Swedish economy passed through a period of structural change which saw the decline of the industrial sector and the emergence of a strong service sector. Nordic labour migration, especially Finnish, gradually declined primarily because of a diminishing gap in the standard of living between the two countries and an increasing demand for labour within Finland. While labour migration dwindled during the 1970s and even more significantly in the 1980s and 1990s, other types of migration started to increase. These new groups were predominantly noneconomic migrants (family reunification) and refugees. This also led to a major shift in the country of origin mix amongst the immigrant population. In the 1970s, the major contributors to the immigrant population in Sweden were primarily refugees from Chile, Poland and Turkey. In the 1980s, the lion's share of this new immigrant contingent came from Chile, Ethiopia, Iran and other Middle Eastern countries. In the mid-1990s, refugee and family reunification policies allowed increasing numbers of immigrants from Iraq, the former Yugoslavia and other Eastern European countries (Bevelander 2004). However, the entrance of Sweden into the European Employment Strategy/European Union (EES/EU) in 1994/1995 rejuvenated labour migration in Sweden, primarily of EU citizens.

\section{Extending the electorate: citizenship and foreign citizens}

Citizenship in Sweden is based on the jus sanguinis principle. People whose parents are Swedish citizens are automatically granted citizenship. However, unlike the case of Canada, the children of non-Swedish citizens who are born in Sweden are not automatically entitled to Swedish citizenship. That aside, Swedish legislation on naturalization is one of the most liberal in Europe. In 2006, 77 percent of eligible foreign-born residents with non-Swedish parents had obtained Swedish citizenship. 
Since the 1970s, foreign citizens from most countries over the age of 18 without a criminal record have been able to acquire Swedish citizenship after five years of residency (or four years for refugees). Foreign citizens from other Nordic countries can obtain citizenship after only two years of residence. ${ }^{4}$ Gaining citizenship by notification is also possible. This is basically a simplified juridical naturalization procedure used mainly by Nordic citizens. In general, acquiring Swedish citizenship by notification is possible if the applicant is 18 years of age or older, has lived in Sweden for five years and has not been sentenced to prison during this time. ${ }^{5}$

Dual citizenship was forbidden in Sweden until July 1, 2001 except in cases where countries did not allow renunciation of citizenship. While many individuals may see uptake of a citizenship as a fairly casual act, renunciation of a citizenship is much more serious. After 2001, no such demands were placed on applicants (Bevelander 2006).

In 1976, foreign citizens were granted the right to vote in municipal and provincial elections after three years of registered residency. The stated goal of this change was to increase the political influence, interest and sense of belonging among foreign citizens (SOU 1975, 15). The three-year waiting period for foreign citizens from EU countries, Iceland and Norway was removed in 1998. Voting in national elections requires Swedish citizenship.

According to Öhrvall (2006), a distinct increasing trend in electoral participation is visible up to the middle of the 1970s. In 1976, 91.8 percent of the electorate voted in the national election (see Figure 1). ${ }^{6}$ This represents the highest level of electoral participation measured in Sweden. Sixty percent of foreign citizens exercised their franchise and voted in municipal and provincial elections in 1976 (see Figure 2). However, this decreased to 36\% by 2006 (SCB 2006).

\footnotetext{
${ }^{4}$ If the foreign citizen is either under 18 or with a criminal record, there is a waiting period before the applicant can apply for Swedish citizenship.

${ }^{5}$ Individuals granted refugee status can apply for citizenship after 4 years.

${ }^{6}$ In Figure 1, voting participation is given based on the 2006 electoral survey. Individuals over the age of

| 75 are included from 1988 on. This means that prior to 1988 the participation rates shown in Figure 1 are somewhat higher than the actual electoral participation for the years up to 1985.
} 


\section{Earlier research}

\section{Social Inclusion \& Voting}

The concept of social inclusion is an elusive term. Although it is accompanied by a burgeoning literature, there is little consensus as to what it means. However, in their review of the social inclusion literature, Toye and Infanti (2004) argue that social inclusion is both an outcome and a process. Arguably, social inclusion is a powerful normative concept that can serve as both a framework and an ideal in areas such as policy-making and community-building. The social inclusion literature states that a fundamental goal of society is to enable its members to participate fully as valued, respected and contributing members (see Toye and Infanti 2004; Laidlaw Foundation 2002; European Union 2001). Indeed, the European Union defines social inclusion as

a process which ensures that those at risk of poverty and social exclusion gain the opportunities and resources necessary to participate fully in economic, social and cultural life and to enjoy a standard of living and well-being that is considered normal in the society in which they live. It ensures that they have a greater participation in decision-making which affects their lives and access to their fundamental rights (European Commission 2005, 10).

The concept of inclusion is linked to that of exclusion. Both are concerned with access to societal resources (be they tangible, such as financial resources or intangible, such as decision-making power).

Much of the social inclusion literature focuses upon tangible and required activities such as working, or access to a dwelling. However, in our view these are non-negotiable. People need a place to live and by and large families require an income, generally based on employment. There is little choice, and therefore these measures may not reflect actual inclusion. Voluntary involvement on the other hand, such as membership in organizations, charitable activity and voting, may therefore be better markers of inclusion than income and employment. Under the European Union definition for social inclusion, one can view the act of casting a ballot in elections as an indicator of inclusion - it is both a measure of participation and ultimately connected to the decision making process 
(European Commission 2005). Indeed voting is completely voluntary and does not involve a negative sanction for non participation

Within the context of political engagement, Burchardt et al. (2002) argue that simple participation in elections through voting can constitute an important measure of inclusion because it taps the degree to which individuals feel that they should take part in the decision-making process at a very broad level.

Many studies have tried to identify factors that affect the likelihood and nature of voting behaviour for the population as a whole. However, studies that include an analysis of the voting behaviour of immigrants and their descendants are far less frequent in part because of lack of data and in part because immigrants are generally not given voting privileges until after attaining citizenship. This means that there are relatively few studies which look at voting and immigrant status and even fewer that include foreign citizens.

Two general themes have emerged in the literature. First, immigrants vote less than native-born; and second, the factors that result in the decision to vote differ by immigrant status and country of birth.

Multiple studies have found that immigrants are less likely to vote compared to nativeborn citizens (Adman and Strömblad 2000; Oskarsson 2003; Öhrvall 2006; Järnbert and Örhvall 2003). Ramakrishnan and Espenshade (2001) use multiple years of the Current Population Survey (CPS) to measure the probability of voting based on minority status. They find that minorities are substantially less likely to vote in elections compared to native-born majority residents. Using the 1996 CPS, Bass and Casper (2001) find similar results. Chui et al. (1991) used the 1984 Canadian Election Survey (CES) and found that immigrants did vote less compared to non-immigrants. This finding, however, can be further disaggregated to different ethnic sub-groups (Ramakrishnan and Espenshade 2001; Cho 1999). Lien (2004) finds that these differences can extend to the $2^{\text {nd }}$ generation. Sometimes, ethnicity has a greater influence on voting behaviour rather than 
one's place of birth. He finds that Asians born in the United States are less likely to vote than majority-origin citizens.

To what degree are these differences a product of socio-economic and demographic factors? Adman and Strömblad (2000) studied electoral participation of immigrants in Sweden. Using a sample of 3000 individuals from the 1998 election, they find that immigrants are less likely to vote. However, controlling for background factors causes these differences to disappear. They conclude that this is an indication of the effects of naturalization (see also Oskarsson 2003). Öhrvall (2006), using a larger sample of 2002 Swedish election data finds a clear difference in participation between foreign-born citizens and non-citizens. However, after controlling for various background factors, he finds only a small difference in electoral participation between foreign-born and Swedish-born children of immigrants. He argues that the exclusion of immigrants from national elections, which receive most attention in the media, reduces peoples' inclination to vote in municipal and provincial elections. He also argues that for immigrants who are not socialized in the Swedish political system, local elections are the least interesting (Öhrvall 2006; see also Bäck and Soininen 1994).

A similar assertion was discovered in Canadian studies. Using the Canadian Election Survey data, White et al. (2006), found that immigrants in general have similar voting participation rates to the native-born after controlling for education and income.

Likewise, using the 2002 wave of the Equality Security Community Survey, Bevelander and Pendakur (2009) found that the combination of socio-demographic and social capital attributes largely overrides the impact of immigration and ethnicity and suggest that it is not the minority attribute that impacts voting.

Looking specifically at various factors that impact voting behaviour, a survey of the literature and studies conducted show that different variables can affect an individual's voting probability positively, negatively or none at all. Tuckel and Meisel (1994), who look at voting by European minorities living in the United States, argue that demographic and socio-economic factors, such as age, education and labour force characteristics are 
the dominant factors in explaining voting probabilities (see also DeSipio 1996; Bass and Casper 2001; Verba et al. 1995).

In Sweden, Öhrvall (2006) found that women are more likely to vote than men, employed more than unemployed, with participation also increasing with age, income and higher educational level. Prior to this study, Järnbert and Örhvall (2003) identified the same variables as having an influence on the voting behaviour of individuals.

Ramakrishnan and Espenshade (2001) extend the model of immigrant voting behaviour by adding controls for generation, language proficiency (in English), duration of stay, ethnic residential concentration and political socialization in the home country. Across generations, they find different patterns in voting participation among different racial/ethnic groups. Except for Black and Asian-American immigrants, a longer stay in the United States increases the probability of voting. Being an immigrant from a repressive regime has a weak negative effect on voting participation. Language proficiency, as measured by the presence of Spanish-language ballots and proximity to co-ethnics (measured at a state level) did not have a strong effect on the probability of voting. They did find, however, that the political culture in a state influences voting behaviour.

There has been some evidence which suggests that citizenship acquisition may be important in the decision to vote. Öhrvall (2006) argues that immigrants who obtain Swedish citizenship are more committed to the country than non-citizens and therefore, are more inclined to vote (Öhrvall 2006). Messina (2006), while comparing voting results for the latest elections by citizens and non-citizens in a number of European countries, argues that obtaining citizenship and increased years of residency in the country are positively related to higher rates of electoral participation. Similar to the latter finding, White et al. (2006) found that as the length of residency increases, voting probability of immigrants also increases. However, Ramakrishnan and Espenshade (2001) challenge these claims arguing that differences in voting probabilities are not always reduced from one generation to another. 
The preceding review suggests that there are some areas of contention regarding the reasons immigrants have lower voting rates. Evidence from the United States (see DeSipio 1996; Bass and Casper 2001; Verba et al. 1995; Tuckel and Meisel 1994) suggests that differences are largely a result of demographic and socio-economic factors. Evidence from Europe and Canada (see for example Chui et al 1991; Öhrvall 2006; Messina 2006) point to issues related to socialization and integration. Another area of particular interest in Europe is the impact of citizenship acquisition on voter participation. The fact that non-citizens can vote in local elections in a number of European countries opens up the debate to questions related to the intrinsic value of citizenship as a measure of belonging and thus inclusion.

It is also clear that voting can be viewed as constituting a grounded measure of inclusion (see Burchardt et al 2002). Thus measuring the independent effect of immigrant status on voting, after controlling for demographic and socio-economic factors could offer a useful measure of the degree to which minorities are included in Swedish society. Further given that citizenship can be viewed as a measure of inclusion, it may have a real impact on peoples willingness to engage in societal decisions, such as voting.

Our goal is to examine the link between two largely symbolic and yet important measures of inclusion and belonging - that of citizenship acquisition and voting. In the Swedish context, and indeed in many other countries, neither action incurs substantial negative consequences to non-participation - the cost of not acquiring citizenship in Sweden is minor and, the cost of not voting is negligible. Yet both are indictors of peoples' sense of belonging and willingness to participate. Thus we ask, after controlling for a range of socio-economic, demographic and contextual factors, to what degree do we find differences in voting probabilities across country of birth groups and generation and to what degree are these differences mitigated by the acquisition of citizenship. 


\section{Data and method}

The Swedish 2006 Electoral Survey contains information on individual electoral participation for a sample of eligible voters in national, provincial and municipal elections. This information is then matched to registry data from Statistics Sweden, which contains demographic and socio-economic information for every Swedish resident. We then matched city of residence information from this sample to the 2006 Swedish register data in order to add municipal characteristics to the base. Combining these sources of information allows us to run weighted instrumental variable regressions to explore the relationship between socio-economic and immigrant characteristics on voting in the 2006 municipal election controlling for citizenship acquisition. In total, we have information for 70,932 Swedish residents, a third of whom are immigrants $(23,678)$. More than half of the immigrants $(12,790)$ are not citizens but have the right to vote in municipal and provincial elections.

We run three types of regressions. The first set, for all Swedish residents are normal OLS regressions where the dependent variable is whether the respondent voted in the 2006 municipal election. For people born outside Sweden, we run instrumental regressions where the dependent variable is whether an individual has voted in the 2006 municipal election. Suppose that individuals that acquire citizenship are also more likely to vote because both are forms of participation and people who participate in voting are also likely to take out citizenship. In order to remove the bias caused by both actions being forms of participation we use citizenship acquisition rules and the years since eligible for citizenship as an instrument for citizenship. The rules are as follows:

1. Immigrants from Nordic countries who have lived in Sweden for two or more years are eligible for citizenship. For Nordic immigrants, the number of years in Sweden after 2 years of residence is assumed to be the number of years he or she has been eligible for citizenship, and;

2. Immigrants from other countries are eligible to apply for citizenship after five years. The number of years after this is considered to be the number of years he or she has been eligible for citizenship. 
By instrumenting citizenship in this way, we interpret the coefficient for citizenship as the 'clean' effect of citizenship on voting (without the impact of participation that is correlated with voting).

We also run separate instrumental variable regressions for each of the 9 country of birth groups. This is equivalent to a model in which all variables are interacted with country of birth.

We include fourteen variable types in our models. Contextual variables, drawn from the registry include the log of the city population, the log of the immigrant population, the local unemployment rate for the city, and foreign-born municipal council representation. ${ }^{7}$ Demographic variables include age (six dummy variables), sex (a dummy for males), marital status (four dummy variables), a dummy variable indicating whether there are children in the household and a dummy variable indicating whether the spouse is Swedish.

Socio-economic variables include income quintile (six dummy variables including no income), housing tenure (three dummy variables), schooling (five dummy variables) and schooling interacted with whether the last level of schooling was outside Sweden (for a total of 10 dummy variables). For regression with all Swedish residents, we include country of origin (12 dummy variables, including two dummy variables that define the number of immigrant parents a Swedish-born respondent has), years since immigrating and citizenship. ${ }^{8}$ For residents born outside Sweden we include 9 dummy variables for country of birth groups.

Of the variables included, housing tenure and income from work are generally recognized as 'hard' social inclusion indictors (see Ministry of Health and Social Affairs 2007). We consider having a partner who is Swedish, the presence minorities on municipal councils

\footnotetext{
${ }^{7}$ Information on the log of city size and the log of immigrant population for each respondent is drawn from the Registered Total Population (RTB) database 2006. The municipal employment rate is drawn from 2007 Statistics Sweden data and the proportion of foreign-born council members is drawn from Democracy Statistics 2007 (Statistics Sweden 2007).

${ }^{8}$ We use the EU 25 definition for our EU (non-Nordic category).
} 
and citizenship acquisition to be 'soft' indicators of social inclusion. The rest of the controls included in the model are there because they have been seen to be correlated with voting. We thus have to control for them in order to understand the impact of variables we see as related to social inclusion.

\section{Results}

\section{Descriptives}

Table 1 shows the proportion of people who voted in the 2006 municipal election by selected characteristics. As can be seen, the overall rate of voting is high. Eighty percent of the population voted in the 2006 municipal election. However, the results from Table 1 suggest that there are substantial differences by age, place of birth, income and level of schooling. As suggested by the literature, younger citizens are less likely to vote. Only 69 percent of those less than 25 years old voted in the municipal election as compared to $86 \%$ of 55 to 64 year olds. People who are not married are also less likely to vote than those who are married. Having a partner who is Swedish makes a big difference. Nine out of ten people with Swedish partners voted. As schooling increases, the proportion of people who vote also increases, however obtaining the last level of schooling outside Sweden has a strong negative effect - only $60 \%$ of people in this category voted, as compared to $82 \%$ who were schooled in Sweden. Income makes a substantial difference. Only about half of people with no income voted, whereas over 90 percent of people in the top quintile voted. Renters are less likely to vote as compared to owners. Being born outside Sweden generally results in lower voting probabilities. Less than 60 percent of immigrants from Europe, Africa, the Middle East and East Asia voted. However over 60 percent of immigrants from the Americas and South Asia voted. Non-citizens are less likely to vote - just over a third of non-citizens voted in the 2006 municipal election.

To summarize, being born outside Sweden and not being a citizen appear to be fairly powerful determinants of voting. As income and schooling increase, the proportion of non-citizen voters decreases. Thus, at least at the level of the descriptive information there is broad agreement with previous research. The question we ask is: to what degree do contextual and individual characteristics override those of immigrant status? And how 
important is citizenship in determining voting propensities and enhancing social inclusion?

\section{Results from OLS regressions:}

Table 2 shows results from an OLS regression in which the dependent variable is whether the respondent voted controlling for a range of contextual, demographic and socioeconomic characteristics. The sample includes all eligible voters in Sweden regardless of citizenship.

Looking first at contextual variables, it appears that the characteristics of the municipality of residence make a difference. The larger the city, the less likely people are to vote. However, the larger the immigrant population, the more likely people are to vote. The employment rate also makes a difference. Full employment increases voting by 0.10 . However having minorities on council does not make a significant difference in voting.

There are some interesting differences between results in Table 1 and Table 2. Whereas age was broadly linear in Table 1, Table 2 reveals that people age 25 to 44 are less likely to vote than people in the comparison group (less than 25 years old). Marital status has only a small (and generally insignificant impact) on voting. Having a spouse who is Swedish, however, continues to have a strong impact, raising voting by 0.07 . Results for income and schooling are in line with those seen in Table 1. As income and schooling rise, the probability of voting also rises. Obtaining the last level of schooling from outside Sweden has a small negative effect (0.03) but there is no additional effect by level of schooling.

Country of birth also makes a difference to the probability of voting. First, as compared to being born in Sweden, being born outside Sweden results in lower (often much lower) probabilities of voting. In particular, being born in Europe outside the EU (and Nordic countries), or being born in East Asia, lowers voting by -0.22 and -0.21 respectively. Being born in Sweden, even if the respondent has immigrant parents, raises the coefficient for voting compared to those born outside Sweden. Having two immigrant 
parents lowers voting by -0.08 , while having one immigrant parent and one Swedish parent lowers voting by -0.03 .

Acquiring citizenship has the strongest positive effect on voting (0.25), outweighing both schooling and income. However, this result is biased for several reasons. First, all Swedes are citizens, thus, the citizenship variable is picking up at least part of the impact of being Swedish. Second, it may be that citizenship is picking up part of the impact of voting by immigrants who acquired citizenship as an extension of their participation - in other words they voted before they acquired citizenship as well. Thus simple OLS regression does not allow us to interpret the clean effect of citizenship (devoid of the impact of high participators). In the next section we use Instrumental Variable (IV) regression to control for the impact participation on citizenship for the immigrant population. $^{9}$

\section{Results from IV regressions:}

Table 3 shows results from ten IV regressions where the dependent variable is whether the respondent voted controlling for a range of contextual, personal and socio-economic variables and where the instrumented variable is citizenship based on eligibility for citizenship and years since eligible for citizenship. Regression 1 provides results for all people born outside Sweden. Regressions 2 through 10 provide results for individual place of birth groups. This is equivalent to Regression 1, but interacting place of birth with all the other variables.

Looking first at the results for all immigrants born outside Sweden (Regression 1) we see that contextual variables in general, do not have significant impacts. Unlike the case for the total population, city size, number of immigrants and employment rate do not affect immigrant voter participation. Among the demographic variables, having a Swedish partner and having children have strong positive effects on voting (0.14 and 0.06 respectively).

\footnotetext{
${ }^{9}$ It could be argued that we have the same challenge with the number of years since an immigrant arrived in Sweden. Interacting citizenship with years in the country would solve this problem to a degree, but it is our contention that the IV regressions solve both problems.
} 
Higher levels of schooling are associated with higher voter participation. However there is no significant impact on attaining schooling outside Sweden. Thus, in terms of voting, if you are an immigrant, it does not appear to matter where you obtained your schooling. As is to be expected, the impact of income is strong and positive. Immigrants in the highest income quintile are much more likely to vote as compared to immigrants without any income.

Looking at Table 3 we can see that country of birth remains significant as an explanatory variable in voter participation. As compared to immigrants from North America, immigrants from immigrants from Europe and East Asia have lower voting rates. However immigrants from South America are more likely (coefficient of 0.06). The rest of the country of birth groups have about the same voting rates.

As will be recalled, from the results in Table 2, citizenship was seen to be a powerful determinant of voter participation, even though citizenship is not required to vote in a municipal election. However it could be argued that in Table 2, the impact of citizenship was biased by the impact of an individual's willingness to participate. Table 3 controls for this by instrumenting citizenship as a product of eligibility for citizenship and years since an immigrant has been eligible for citizenship. Looking at the coefficient for citizenship in Table 3 we can see that although much weaker than was the case in Table, it is still amongst our strongest predictors - equal in strength to being in the top two income quintiles, having a Swedish partner or having the highest level of schooling. The impact of time in Sweden is very small (.002 for every year).

It may be that the results we are seeing for the total immigrant population are driven by a small number of country of birth groups. For example, if citizenship is strongly significant for a large group like Nordics it is possible that our results for IV regression 1 are just driven by the Nordic population. IV regressions 2 through 10 show results for each of our 9 country of birth groups. In this way it is possible to assess differences in coefficients across countries. 
Overall, there are only small differences in the magnitude of coefficients between countries. Basically, across all models, the impacts of city characteristics are similar across groups. There are some differences by demographic characteristics. Being young and North American is correlated with higher rates of voting, however for other place of groups, results are similar to those seen for all immigrants. Having a Swedish partner is particularly important for African immigrants (coefficient is 0.23 ) but has no impact for immigrants from North America.

Level of schooling only significant for Nordic, immigrants from the EU and North Americans, however there is no significant impact for other groups. Obtaining the last level of schooling outside Sweden has a negative impact for South Americans and people from the rest of Europe (-0.20 and -0.21 respectively) but is strongly positive for immigrants from the Middle East and from Nordic countries (0.25 and 0.16 respectively). In most cases, the impact of income follows a similar pattern to that seen for all immigrants.

Finally, citizenship is strongly positive for immigrants from Nordic countries and South Asia (0.54 and 0.35 respectively) and moderately strong for immigrants from the Middle East (0.12). Citizenship does not have a significant impact for other countries. This suggests that the strong positive impact we saw in IV regression 1 was driven by immigrants from Nordic countries, the Middle East and South Asia. Years in Sweden has a strong positive effect for only two countries - Middle East and East Asia. What this suggests is that citizenship is far more important to participation for some groups than others. However at the same time, it should be recognized that roughly half of all immigrants come from these three regions. Further, for these three groups, citizenship is always one of the most important explanatory factors in determining voting.

\section{Conclusions}

Much of the social inclusion literature concentrates on “hard” activities. Sweden’s Strategy Report for Social Protection and Social Inclusion 2006-2008 for example 
examines access to housing, segregation and work (Ministry of Health and Social Affairs 2007). In our view, voting is a "soft" measure of social inclusion that is related to willingness to participate and sense of belonging. As well, voting could be considered an indicator related to the health of democracies. While the overall rate of voting may differ across countries, large differences between groups of eligible voters within a country may indicate a potential problem. This is especially the case given the impact of globalization and migration, which will be increasingly important in western democracies.

Housing tenure and income are useful and typical measures of inclusion, however, we would argue that voting is at least as useful a measure because there is a degree of choice. People have to work, must have housing and ideally should not have to be ethnically segregated. There is little individual-level choice in these measures. As such, they may not be good measures of social inclusion - rather they are indictors of integration. Voting is different. You don't have to vote, but voting does allow the individual to express an opinion and affect a societal outcome. Further, if inclusion is about participation then voting is an effective measure of social inclusion because it taps a purely voluntary willingness to participate (see Burchardt et al. 2002).

In the same way, citizenship acquisition can be viewed as a measure of inclusion and belonging because it is a reflection of an immigrant's willingness to be part of the larger host society. The cost to not taking up citizenship, especially in Sweden is low. Despite this, it appears that citizenship does have a real and significant impact on people's willingness to participate in the electoral process.

The goal of our study is largely to examine the impact of a set of hard and soft social inclusion indictors upon a soft indictor of social inclusion (that of voting). Our "hard" measures of social inclusion include housing tenure and income. We find that in most cases, immigrants who rent are less likely to vote than immigrants who own their dwelling. Being in one of the top income quintiles increases the probability of voting, but immigrants in the bottom three fifths of the income tend to have about the same probability of voting. 
Our soft indictors of social inclusion include having a Swedish spouse and the impact of citizenship acquisition. Both these variables were found to have some of the highest impacts on the probability of voting, being equal in impact to either of our two "hard" indictors. It may be that citizenship offers people the opportunity to see that they have a stake in what is happening politically in the host country. 


\section{References}

Adman, P. and P. Strömblad. 2000. Resurser för politisk integration, in Utanför Demokratin? Del 3. Norrköping: Integrationsverkets rapportserie 200:16.

Bäck, H. and M. Soininen. 1994. Invandrarnas valdeltagande, in Bäck, H. and A. Håkansson (editors), Väljare i kommunvalet. Om missnöje, misstroende och politisk kultur. Stockholm: SNS förlag.

Bass, L. E. L. M. and Casper. 2001. Impacting the political landscape: Who registers and votes among naturalized Americans?, in Political Behavior 23 (2): 103-130.

Bevelander, P. 2004. Immigration patterns, economic integration and residential segregation; Sweden in the late $20^{\text {th }}$ century, in Current Themes in IMER Research, No 2., Malmö University.

Bevelander, P. 2006. The Integration Challenges of Sweden in Usha George (ed.), Canadian Diversity, Association of Canadian Studies, 5 (1): 86-91.

Bevelander, P. and R. Pendakur. Forthcoming. Social capital and voting participation of immigrants and minorities in Canada, Ethnic and Racial Studies.

Burchardt, T. et al. 2002. Introduction, in John Hills, Julian LeGrand and David Piachaud (eds.), Understanding Social Exclusion. Oxford: Oxford University Press.

Byrne, D. 1999. Social Exclusion. Buckingham: Open University.

Cho, T. 1999. Naturalization, socialization, participation: Immigrants and (non-) voting, in The Journal of Politics 61 (4): 1140-1155.

Chui, T., J. Curtis, and R. Lambert. 1991. Immigrant background and political participation: examining generational patterns, Canadian Journal of Sociology 16 (4): 375-396.

Cushing, P. 2003. Policy approaches to framing social inclusion and social exclusion: An overview. Toronto: Roeher Institute.

Dawson, M. and L. Bobo. 2006. The more things change: Continuity and change in American racial landscape, in Du Bois Review: Social Science and Research on Race 3 (2): 257.

DeSipio, L. 1996. Making citizens or good citizens? Naturalization as predictor of organizational and political behavior among Latino immigrants, in Hispanic Journal of Behavior Sciences 18: 195-213. 
European Commission. 2005. Report on Social Inclusion 2005: An Analysis of the National Action Plans on Social Inclusion (2004-2006) submitted by the $10 \mathrm{New}$ Member States.

European Union Social Protection Committee. 2001. Report on Indicators in the Field of Poverty and Social Exclusion. JGM: http://ec.europa.eu/employment_social/news/2002/jan/report_ind_en.pdf

Gordon, D. 1970. Immigrants and municipal voting turnout: Implications for the changing ethnic impact on urban politics, in American Sociological Review 35 (4): 665-681.

Gordon, D., R. Levitas, C. Pantazis, et al. 2000. Poverty and Social Exclusion in Britain. York: Joseph Rowntree Foundation.

Hammar, T. 1979. Det första invandrarvalet. Stockholm: Liber förlag.

Järnbert, M. and R. Öhrvall. 2003. Det svenska valdeltagandet, in Vogel, J. (ed.), Väfärd och ofärd på 90-talet. Stockholm: Statistiska centralbyrån.

Jedwab, J. 2006. The 'roots' of immigrant and ethnic voter participation in Canada, in Electoral Insight, Electoral Participation of Ethnocultural Communities 8 (2).

Kaufmann, K. M. 2007. Immigration and the future of Black power in U.S. cities, Du Bois Review: Social Science and Research on Race 4 (1): 79-96.

Laidlaw Foundation. 2002. The Laidlaw Foundation's Perspective on Social Inclusion. Toronto: The Laidlaw Foundation, 2002.

Lien, P. 2004. Asian Americans and voting participation: Comparing racial and ethnic differences in recent U.S. elections, in International Migration Review 38 (2): 493-517.

Lundh, C. And R. Ohlsson. 1999. Från arbetskraftsimport till flyktinginvandrig. Stockholm; SNS förlag.

Messina, A. M. 2006. The political incorporation of immigrants in Europe: Trends and implications”, in Messina. A. M. and G. Lahav (eds.), The Migration Reader, Exploring Politics and Policies. Boulder/London: Lynne Rienner Publishers.

Ministry of Health and Social Affairs. 2007. Sweden's Strategy Report For Social Protection And Social Inclusion 2006-2008. Stockholm: Sweden.

Öhrvall, R. 2006. Invandrade och valdeltagande, in Bäck, H. and M. Gilljam (eds.), Valets Mekanismer. Malmö: Liber förlag. 
Oskarsson, S. 2003. Vem röstar och varför? En analys av valdeltagandet i 2002 års kommunfullmäktigeval. Stockholm: Justitiedepartementet, Ds 2003:54.

Palermo, F and J. Woelk. 2003. "From Minority Protection to a Law of Diversity? Reflections on the Evolution of Minority Rights", 3 European Yearbook of Minority Issues 5-13.

Putnam, Robert D. (2007). E Pluribus Unum: Diversity and community in the twentyfirst century: The 2006 Johan Skytte Prize Lecture. Scandinavian Political Studies 30 (2): 137-174.

Ramakrishnan, S. K. and T. Espenshade. 2001. Immigrant incorporation and political participation in the United States, in International Migration Review 35 (3): 870909.

Rodgers, G. 1995. What is special about a 'social exclusion' approach?, in International Labour Organization (ILO), Social Exclusion: Rhetoric, Reality, Responses. Geneva: ILO (International Institute for Labour Studies).

SCB (Statistics Sweden), Allmänna valen 2006 Del 4.

SCB (Statistics Sweden), (2007) Democracy Statistics Report no 7: Elected representatives in municipalities and county councils 2007: A report on the number of politicians and representativity.

Statens offentliga utredningar (SOU) 1975:15.

Toye, M. and J. Infanti. 2004. Social Inclusion and Community Economic Development Literature Review. Ottawa: The Canadian CED Network.

Tuckel, P. and R. Maisel. 1994. Voter turnout among Europeans immigrants to the United States, in Journal of Interdisciplinary History 24 (3): 407-430.

Verba, S., K. Lehman-Shlozman and H. Brady. 1995. Voice and Equality. Civic Voluntarism in American Politics. Cambridge: Harvard University Press.

White, S. et al. 2006. Making up for lost time, immigrant voter turnout in Canada, in Electoral Insight, Electoral Participation of Ethnocultural Communities 8 (2).

White, S. and I. McAllister. 2007. Turnout and representation bias in postCommunist Europe, in Political Studies 55 (3): 586-606.

Winstanley, D. and C. Stoney. 2000. Inclusion in the workplace: The stakeholder debate, in Peter Askonas and Angus Stewart (eds.), Social Inclusion: Possibilities and Tensions. New York: St. Martin’s Press. 
Table 1

Descriptive Statistics, Proportion who voted in the 2006 municipal election, by selected characteristics

\begin{tabular}{|c|c|c|c|}
\hline & & did not vote & voted \\
\hline Total & & $20 \%$ & $80 \%$ \\
\hline \multirow[t]{6}{*}{ Age } & $<25$ & $31 \%$ & $69 \%$ \\
\hline & $25-34$ & $25 \%$ & $75 \%$ \\
\hline & $35-44$ & $20 \%$ & $80 \%$ \\
\hline & $45-54$ & $17 \%$ & $83 \%$ \\
\hline & $55-64$ & $14 \%$ & $86 \%$ \\
\hline & $65+$ & $21 \%$ & $79 \%$ \\
\hline \multirow[t]{2}{*}{ Sex } & Males & $21 \%$ & $79 \%$ \\
\hline & Females & $20 \%$ & $80 \%$ \\
\hline \multirow[t]{4}{*}{ Martal Status } & Single & $26 \%$ & $74 \%$ \\
\hline & Married & $13 \%$ & $87 \%$ \\
\hline & Divorced/separated & $25 \%$ & $75 \%$ \\
\hline & Widowed & $29 \%$ & $71 \%$ \\
\hline \multirow[t]{2}{*}{ Swedish Spouse } & Partner not Swedish & $27 \%$ & $73 \%$ \\
\hline & Partner is Swedish & $9 \%$ & $91 \%$ \\
\hline \multirow[t]{2}{*}{ Presence of Children } & no children & $21 \%$ & $79 \%$ \\
\hline & Children in household & $17 \%$ & $83 \%$ \\
\hline \multirow[t]{5}{*}{ Schooling } & $<2$ ndary & $27 \%$ & $73 \%$ \\
\hline & Lower 2ndary & $19 \%$ & $81 \%$ \\
\hline & Upper 2ndary & $21 \%$ & $79 \%$ \\
\hline & Lower university & $12 \%$ & $88 \%$ \\
\hline & Upper university & $9 \%$ & $91 \%$ \\
\hline \multirow[t]{2}{*}{ Place of Schooling } & last level in Sweden & $18 \%$ & $82 \%$ \\
\hline & last level outside Sweden & $39 \%$ & $61 \%$ \\
\hline \multirow[t]{6}{*}{ Income Quintile } & No income & $44 \%$ & $56 \%$ \\
\hline & q1 & $31 \%$ & $69 \%$ \\
\hline & $q 2$ & $23 \%$ & $77 \%$ \\
\hline & q3 & $18 \%$ & $82 \%$ \\
\hline & q4 & $14 \%$ & $86 \%$ \\
\hline & q5 & $9 \%$ & $91 \%$ \\
\hline \multirow[t]{3}{*}{ Tenure } & own house & $14 \%$ & $86 \%$ \\
\hline & own apartment & $20 \%$ & $80 \%$ \\
\hline & rent & $30 \%$ & $70 \%$ \\
\hline \multirow[t]{12}{*}{ Country of Birth } & Sweden & $16 \%$ & $84 \%$ \\
\hline & Nordic & $42 \%$ & $58 \%$ \\
\hline & EU non-Nordic & $43 \%$ & $57 \%$ \\
\hline & Rest of Europe & $48 \%$ & $52 \%$ \\
\hline & Africa & $49 \%$ & $51 \%$ \\
\hline & N. America & $35 \%$ & $65 \%$ \\
\hline & S. America & $35 \%$ & $65 \%$ \\
\hline & Middle East & $43 \%$ & $57 \%$ \\
\hline & E. Asia & $47 \%$ & $53 \%$ \\
\hline & S. Asia & $37 \%$ & $63 \%$ \\
\hline & 2 immigrant parents & $31 \%$ & $69 \%$ \\
\hline & 1 immigrant parent & $21 \%$ & $79 \%$ \\
\hline \multirow[t]{2}{*}{ citizen } & Not a Citizen & $63 \%$ & $37 \%$ \\
\hline & Swedish Citizen & $18 \%$ & $82 \%$ \\
\hline
\end{tabular}


Table 2: Results from OLS regressions where the dependent is voted in the 2006 municipal election

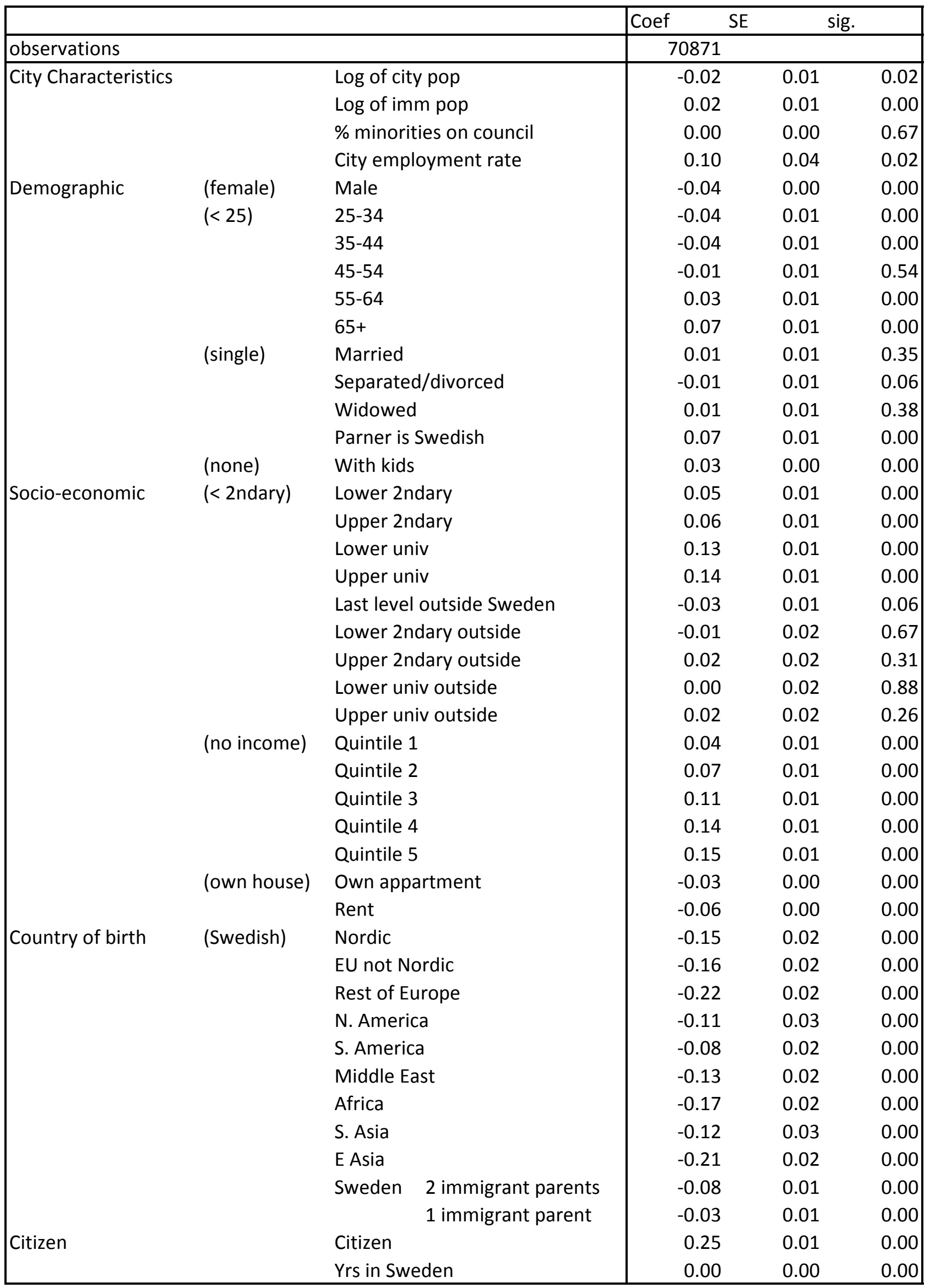


Table 3: Results from Survey 2 Stage Least Squares Instrumented Regressions

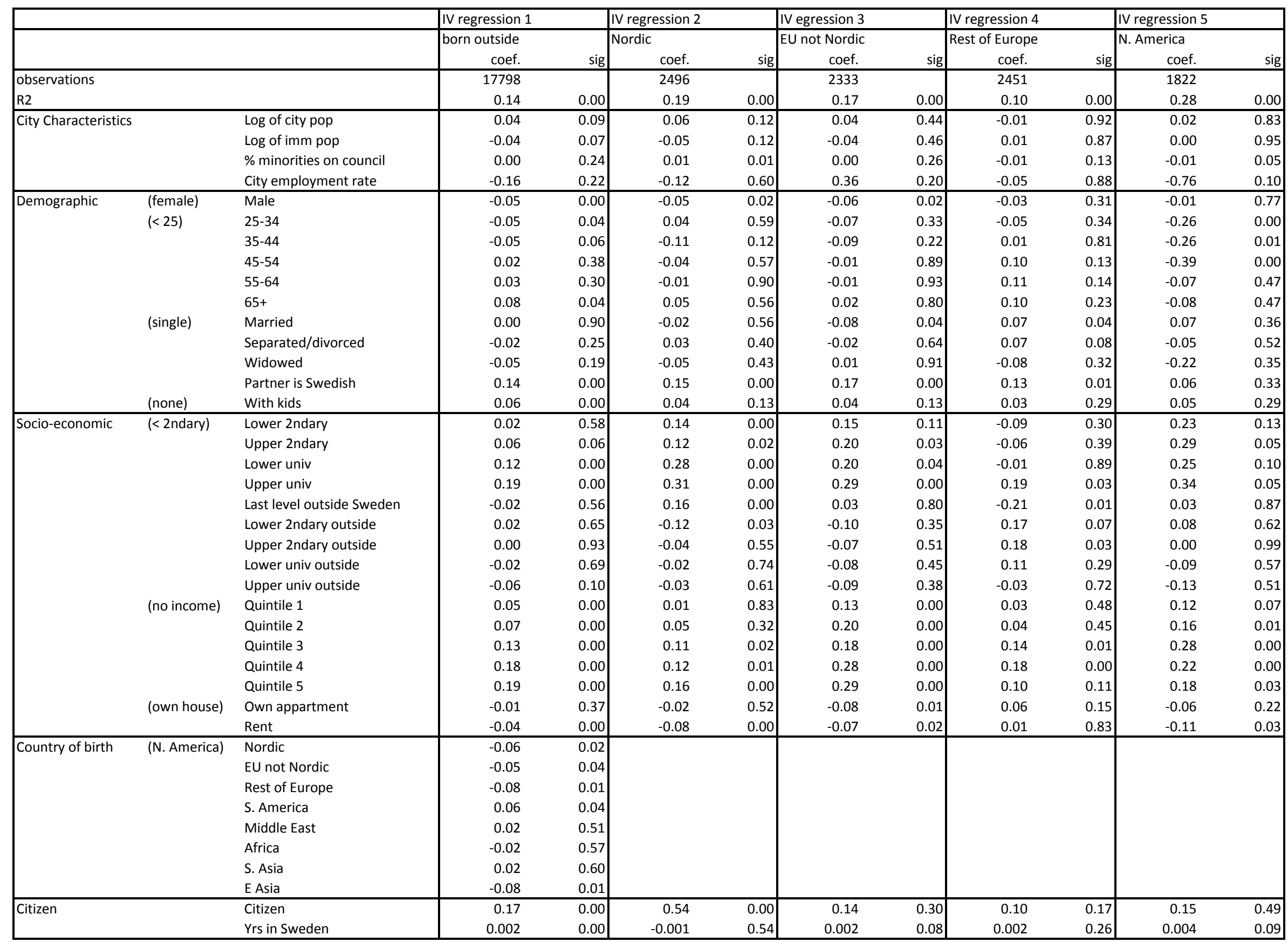


Table 3: Results from Survey 2 Stage Least Squares Instrumented Regr

\begin{tabular}{|c|c|c|c|c|c|c|c|c|c|c|c|c|}
\hline & & & IV regression 6 & & IV regression 7 & & IV regression 8 & & IV regression 9 & & IV regression 10 & \\
\hline & & & S. America & & Africa & & Middle East & & S. Asia & & E Asia & \\
\hline & & & coef. & sig & coef. & sig & coef. & sig & coef. & sig & coef. & sig \\
\hline observations & & & 1954 & & 1876 & & 3077 & & 842 & & 947 & \\
\hline R2 & & & 0.16 & 0.00 & 0.11 & 0.00 & 0.10 & 0.00 & 0.23 & 0.00 & 0.20 & 0.00 \\
\hline City Characteristics & & Log of city pop & 0.10 & 0.19 & -0.05 & 0.60 & -0.06 & 0.34 & -0.07 & 0.43 & 0.09 & 0.26 \\
\hline & & Log of imm pop & -0.11 & 0.10 & 0.04 & 0.61 & 0.05 & 0.35 & 0.05 & 0.57 & -0.08 & 0.26 \\
\hline & & $\%$ minorities on council & 0.01 & 0.28 & -0.01 & 0.14 & 0.00 & 0.43 & -0.01 & 0.55 & -0.01 & 0.08 \\
\hline & & City employment rate & -0.75 & 0.08 & 0.02 & 0.97 & -0.33 & 0.29 & -1.38 & 0.01 & -1.02 & 0.04 \\
\hline Demographic & (female) & Male & -0.06 & 0.12 & -0.03 & 0.51 & -0.06 & 0.01 & -0.01 & 0.90 & -0.11 & 0.01 \\
\hline & $(<25)$ & $25-34$ & -0.03 & 0.70 & 0.05 & 0.52 & -0.06 & 0.17 & 0.14 & 0.07 & -0.18 & 0.02 \\
\hline & & $35-44$ & 0.06 & 0.49 & 0.14 & 0.12 & -0.02 & 0.65 & 0.20 & 0.03 & -0.19 & 0.03 \\
\hline & & $45-54$ & 0.19 & 0.05 & 0.15 & 0.15 & 0.07 & 0.22 & 0.18 & 0.07 & -0.07 & 0.50 \\
\hline & & $55-64$ & 0.20 & 0.05 & 0.08 & 0.54 & 0.08 & 0.21 & 0.17 & 0.14 & 0.03 & 0.82 \\
\hline & & $65+$ & 0.08 & 0.43 & 0.04 & 0.77 & -0.08 & 0.25 & 0.32 & 0.01 & 0.07 & 0.54 \\
\hline & (single) & Married & -0.09 & 0.08 & 0.03 & 0.66 & -0.04 & 0.25 & -0.07 & 0.31 & -0.03 & 0.59 \\
\hline & & Separated/divorced & -0.05 & 0.30 & -0.08 & 0.23 & -0.13 & 0.00 & -0.30 & 0.00 & -0.15 & 0.01 \\
\hline & & Widowed & 0.06 & 0.54 & 0.14 & 0.44 & -0.11 & 0.29 & -0.12 & 0.40 & -0.53 & 0.00 \\
\hline & & Partner is Swedish & 0.17 & 0.00 & 0.23 & 0.00 & 0.04 & 0.54 & 0.13 & 0.01 & 0.10 & 0.06 \\
\hline & (none) & With kids & 0.07 & 0.04 & 0.02 & 0.58 & 0.10 & 0.00 & 0.07 & 0.12 & 0.06 & 0.12 \\
\hline Socio-economic & (<2ndary) & Lower 2ndary & -0.08 & 0.42 & -0.21 & 0.16 & 0.04 & 0.61 & -0.38 & 0.00 & -0.03 & 0.82 \\
\hline & & Upper 2ndary & -0.01 & 0.94 & -0.27 & 0.05 & 0.10 & 0.16 & -0.14 & 0.20 & 0.16 & 0.20 \\
\hline & & Lower univ & 0.13 & 0.19 & -0.11 & 0.46 & 0.07 & 0.33 & -0.25 & 0.04 & 0.25 & 0.05 \\
\hline & & Upper univ & 0.12 & 0.25 & -0.19 & 0.22 & 0.25 & 0.00 & -0.01 & 0.90 & 0.11 & 0.41 \\
\hline & & Last level outside Sweden & -0.20 & 0.04 & -0.17 & 0.20 & 0.03 & 0.62 & -0.04 & 0.73 & 0.02 & 0.90 \\
\hline & & Lower 2ndary outside & 0.30 & 0.01 & 0.12 & 0.45 & -0.01 & 0.91 & 0.27 & 0.07 & 0.07 & 0.65 \\
\hline & & Upper 2ndary outside & 0.28 & 0.01 & 0.12 & 0.42 & -0.10 & 0.21 & 0.13 & 0.35 & -0.20 & 0.16 \\
\hline & & Lower univ outside & 0.03 & 0.83 & 0.08 & 0.62 & -0.02 & 0.85 & 0.16 & 0.29 & -0.13 & 0.37 \\
\hline & & Upper univ outside & 0.05 & 0.68 & 0.19 & 0.26 & -0.20 & 0.01 & 0.10 & 0.42 & -0.05 & 0.73 \\
\hline & (no income) & Quintile 1 & 0.16 & 0.02 & 0.10 & 0.09 & 0.02 & 0.60 & 0.11 & 0.06 & 0.08 & 0.20 \\
\hline & & Quintile 2 & 0.12 & 0.11 & 0.13 & 0.05 & 0.02 & 0.66 & 0.00 & 0.96 & 0.12 & 0.10 \\
\hline & & Quintile 3 & 0.24 & 0.00 & 0.11 & 0.12 & 0.04 & 0.39 & 0.07 & 0.31 & 0.22 & 0.01 \\
\hline & & Quintile 4 & 0.37 & 0.00 & 0.07 & 0.37 & 0.20 & 0.00 & 0.09 & 0.18 & 0.21 & 0.00 \\
\hline & & Quintile 5 & 0.26 & 0.00 & 0.27 & 0.00 & 0.09 & 0.10 & 0.06 & 0.57 & 0.34 & 0.00 \\
\hline & (own house) & Own appartment & -0.04 & 0.48 & 0.07 & 0.42 & 0.05 & 0.25 & -0.05 & 0.41 & 0.02 & 0.71 \\
\hline & & Rent & -0.05 & 0.25 & 0.14 & 0.06 & 0.03 & 0.42 & -0.04 & 0.40 & -0.11 & 0.01 \\
\hline Country of birth & (N. America) & Nordic & & & & & & & & & & \\
\hline & & EU not Nordic & & & & & & & & & & \\
\hline & & Rest of Europe & & & & & & & & & & \\
\hline & & S. America & & & & & & & & & & \\
\hline & & Middle East & & & & & & & & & & \\
\hline & & Africa & & & & & & & & & & \\
\hline & & S. Asia & & & & & & & & & & \\
\hline & & E Asia & & & & & & & & & & \\
\hline Citizen & & Citizen & -0.11 & 0.68 & 0.16 & 0.14 & 0.12 & 0.05 & 0.35 & 0.00 & -0.15 & 0.41 \\
\hline & & Yrs in Sweden & 0.007 & 0.10 & 0.003 & 0.35 & 0.006 & 0.01 & 0.002 & 0.59 & 0.011 & 0.00 \\
\hline
\end{tabular}

